\title{
Service Quality of Islamic Banks: A Cultural Perspective
}

\author{
Siti Nurul Izzati Mohd Hanafi \\ $\mathrm{PhD}$ Candidate \\ Department of Business Administration \\ International Islamic University Malaysia, Malaysia \\ E-mail: izzati.hanafi@gmail.com \\ Suharni Bt. Maulan \\ Assistant Professor \\ Department of Business Administration \\ International Islamic University Malaysia, Malaysia \\ E-mail: suharni@iium.edu.my \\ Siti Ngayesah Ab. Hamid \\ Lecturer \\ Faculty of Economics and Management \\ National University of Malaysia, Malaysia \\ E-mail: ctngayesah@ukm.edu.my
}

Received: July OI, 2020

doi: I0.4628I/ijibfr.v4i2.685
Accepted: July 20, 2020

Online Published: July 30, 2020

\begin{abstract}
The purpose of this paper is to examine the relationship between culturally-based service quality measure on customer satisfaction and loyalty in the Malaysian Islamic banking context. This study utilises the PAKSERV model, a cultural-based instrument together with additional dimensions compliance from CARTER model. A survey questionnaire was utilised to examine the relationships. Data were analysed using PLS-SEM. The result shows that five of the service quality dimensions have significant relationships with customer satisfaction. Compliance, the additional dimension, had been found to be the most influential. This study also reinforces the relationship between satisfaction and loyalty. The compliance dimension added to the PAKSERV measure that denotes religious belief enhances the cultural elements of service quality measure for Islamic banks.
\end{abstract}

\section{Keywords: Customer Loyalty, Customer Satisfaction, Islamic Banking, PAKSERV, Service Quality.}

\section{Introduction}

Maintaining a high standard of quality is essential in producing products and delivering services. In the context of service industry such as banks, providing a distinguished level of service quality leads to a higher competitive edge (Jain \& Jain, 2015). This applies not only to conventional banks but also to the Islamic bank. An Islamic bank with a high quality of service will be able to cope with the stiff competition from conventional banks and new arrivals to the market (Othman \& Owen, 200I). Not only that, but a high-quality service performance also would lead to satisfaction, loyalty and a higher probability for customers to recommend the bank to someone else (Zeithaml, Berry, \& Parasuraman, 1996). Ensuring customers to be satisfied and loyal is crucial as it would help companies to secure a long-term position in the market and preserves profits (Amine, I998; Veloutsou, Daskou \& Daskou, 2004). Besides, loyal customers also would spread positive word of mouth and willing to pay more for a particular product (Jay, Zhang, \& Bilgihan , 20I5). In order to achieve this, a high-quality service needs to be delivered as it is proven could contribute to customer satisfaction and retention (Kashif, Shukran, Rehman, \& Sarifuddin, 20I5; Kashif, Rehman, \& Pilelienè, 2016). 
Despite the importance of service quality, the tools and scale measuring it are still debatable. In almost three decades, various tools have been developed, which among others include the SERVQUAL scale, Grönroos model, CARTER model, SERVPERF, ROM, and RSQS (Martinez \& Martinez, 20I0). However, most of these traditional models of service quality are sharing the same flaws where the measurement scales are all developed in the Western context (Raajpoot, 2004), which may not be applicable in collectivist countries such as the Asian. Not only that, the most popular measure - SERVQUAL also has been questioned on its applicability to suit different country contexts (Kueh \& Voon, 2007; Ladhari, 2008; Tsoukatos \& Rand, 2007). Consequently, this has led to unsatisfactory and unsuitable marketing strategies in some other countries and other cultural contexts (Laroche, Uelschy, Abe, Cleveland, \& Yannopoulos., 2004). In order to overcome this problem, Raajpoot (2004) has developed a non-Western cultural context model called PAKSERV, which is based on the argument that service quality and customer satisfaction is a cultural phenomenon (Malhotra, Ulgado, Agarwal, Shainesh, \& Wu, 2005). This is supported by the fact that the service delivery process involves human interactions profoundly and as such is influenced by cultural background and sensitivities (Kim \& Aggarwal, 2016) which may present marketing opportunities and challenges. As such, service quality is recommended to be explicitly investigated in accordance with the local cultural conditions (Ladhari, Souiden, \& Ladhari, 20II) or other words, the tools being employed to measure service quality must be aligned with the local cultural setting.

However, even though PAKSERV is culturally based, its applicability in measuring service quality for Islamic banks in a multi-cultural society such as Malaysia is still scarce (Kashif et al., 20I5). Therefore, this study aims to employ the PAKSERV scale with the incorporation of "compliance" dimension in examining the service quality of Malaysian Islamic banks. Though PARKSERV has been used to measure service quality for Islamic banks, in the context of the religious-based institutions particularly, religious element as part of cultural components in consumer decision-making behaviour has not been incorporated. Compliance is an important attribute in service quality measure as it differentiates Islamic banks from the conventional (Othman \& Owen, 200I). The remaining part of this paper is organised as follows: First, literature related to service quality, measurement, and culture are presented. Then, the hypotheses development and research methodology are explained, followed by the analysis and findings. Finally, discussion, conclusion, limitations and suggestion for future research are highlighted.

\section{Literature Review 2.I Service Quality}

Service quality, according to Parasuraman, Zeithaml, and Berry (1988), is a function of pre-purchase customer expectations, perceived process quality, and perceived output quality. In other words, service quality refers to the gap between the customer's expectations of service and perceptions of the service experience. This is in line with Fisk and Grove (I995) which defined service quality as "an assessment of the service one receives compared to his/her expectations regarding it" as well as Reeves and Bednar (I994) who define service quality as a level of service that meets the expectations of customers. In short, service quality refers to two important concepts which are expectation and performance.

From the Islamic perspective, quality in the Arabic language is known as 'itqan' or could be interpreted as 'to arrange or to dispose of things in an artistic and best manner in order to obtain the perfect result' (Shariff, 20I3). Quality or perfection is synonym with God's creation as quoted in the Qur'an chapter 67, verse 3 and chapter 27 verse 88. Not only that, but it was also reported by al-Thabrani that Prophet Muhammad (pbuh) said "Allah loves to see one's job done at the level of itqan" (AlDimasqi, 2006) which shows that the effort of performing a job at the best level is important and relevance with Islamic principle. This is supported by Al-Zaabi (2006), which stated that the goal of attaining perfection is considered to be a form of duty towards society.

In the context of Islamic bank, providing the best quality of service as such is significant, especially because products and services provided by Islamic bank are derived from the Islamic law (shariah), thus are expected to be of high quality. This is supported by Shariff (2013) who said that the effort of doing things perfectly is a type of worship, and as such Islamic bank should provide good service quality as it is line with the bank principle. In the context of a bank in general, service quality is known as a vital and essential value, as banks that offer a distinguished level of service have a higher competitive edge (Jain $\&$ Jain, 2015). Therefore, providing high service quality is considered critical for enhancing long-term relationships with customers, especially in the competitive business environment of modern banking (Camarero, 2007; Hawke \& Heffernan, 2006).

However, as service quality is said to be from customer's point of view (Fisk \& Grove, 1995), measuring customer's perception towards the quality of service provided by an organisation is therefore critical. Despite this, it could only be achieved if the right measurement tools are used (Kashif et al., 2015). In the context of Islamic bank, Othman and Owen (200I) 
introduced an alternative measure of service quality by developing a model named as CARTER which has been tested in many subsequent studies on Islamic banks in different countries (Shafie, Azmi, \& Haron, 2004; Tahir \& Bakar, 2007). CARTER model is based on SERVQUAL with additional dimension called 'Compliance'. However, Raajpoot (2004) argued that a proper measurement of service quality should be culturally sensitive. The explanation in the following sub-section will elaborate further on this issue.

\subsection{Service Quality Measurement and Culture}

In order to decide on the right instrument or model to measure service quality, it is important to analyse the characteristics of the local culture first, which in the case of this study is the Malaysian culture. There are different tools created by past rese archers to explain the attribute of each culture which have been adapted and referred by marketers in the planning of marketing approaches. As this study focuses on the Malaysian context, the Hoftstede dimensions were used to examine the characteristics of the Malaysian culture.

One of the Hoftstede's dimensions is called the 'power distance' which states that each individual in a society is not equal. It expresses the cultural attitude towards inequalities among us. In contrast to the West, Malaysia scores extremely high on this dimension; a score of 100 - which indicates that people accept a hierarchical order in an organisation. On the other hand, Malaysia scores 36 on the dimension of 'uncertainty avoidance' and thus has a low preference for avoiding uncertainty. The dimension 'uncertainty avoidance' is the concern with the way a society deals with the fact that the future can never be known. Low 'uncertainty avoidance' shows that society maintains a more relaxed attitude where practice counts more than principles, and deviance from the norm is more easily tolerated.

These differences between the Asian and Western cultures or specifically how Malaysian differs from the West portrays the need to find and use a tool that could measure culturally sensitive service quality. Therefore, researchers have proposed to complement new dimensions that can increase the comprehensiveness of service quality measurements (Choudhury, 2013). Among others, Raajpoot (2004) developed a cultural context model called as PAKSERV to best suit the collectivist culture of Pakistan. The model was developed through a detailed analysis of the cultural and time-orientation nuances of Asians. Over the years, it has been applied in various studies not only in Asia but also has been tried to measure the service quality of banks in the African setting (Saunders, 2008). The study validated all six dimensions of PAKSERV, and the result shows that these dimensions contribute to service quality measurement in the African context. The PAKSERV scale confirmed several SERVQUAL dimensions which are reliability, tangibility, and assurance but replaced responsiveness and empathy with three new dimensions, namely sincerity, formality, and personalisation. However, in order to tackle the religious value of Islamic bank, this study added 'compliance' adapted from the CARTER model to the tested simultaneously with the other dimensions.

\subsection{Reliability}

Raajpoot (2004) conceptualised reliability as the ability to perform the promised service dependably and accurately. Dependability, in this case, refers to fulfilling promises, including time commitment, while accuracy refers to making a minimum number of mistakes. Reliability could be defined as the firm's ability to perform the service right at the right time. It also indicates that the firm honours its promises without fail and the ability in delivering service accurately must be consistent over a period of time. A recent study conducted by Kashif et al. (2016) in Pakistan had shown that reliability is one of the service quality dimensions that have been proven to significantly contribute to customer satisfaction. Based on this, it is hypothesised:

$H_{I}$. Favourable customer perceptions of reliability positively influence customer satisfaction towards Islamic banks.

\subsection{Tangibility}

Tangibility includes the physical evidence of the service such as physical facilities, the appearance of personnel, tools or equipment used to provide the service, also physical representations of the services, such as a plastic credit card or a bank statement (Parasuraman, Zeithaml, \& Berry, 1985). Tangibility can be seen as the way customers assess the physicality that is own by a service provider where it could experience easily and directly by the customers. Studies conducted by (Kashif et al., 2016) that based in Pakistan shows tangibility as one of service quality dimension that has been proven to significantly contribute towards customer satisfaction. Thus, the study hypothesised:

$H_{2}$. Favourable customer perceptions of tangibility positively influence customer satisfaction towards Islamic banks. 


\subsection{Assurance}

Assurance refers to the employee's knowledge, courtesy, and ability to convey trust and confidence (Berry, Lepkowith, \& Clark, 1988). It presents the customer's evaluation of a service provided by the companies and instils the confidence in guaranteed safety, equal treatment, and competence to perform professionally (Raajpoot, 2004). Hence, assurance can be described as the employees' affirmation and proficiency in providing a courteous and truthful interaction with the customer. Kashif et al. (20I5) recent study on Malaysian Islamic banking adopted the PAKSERV model and revealed that assurance significantly contributes to customer satisfaction, but it was stated as the least important dimension in determining customer satisfaction. Therefore, this study posits that:

\section{$H_{3 .}$ Favourable customer perceptions on assurance positively influence customer satisfaction towards Islamic banks.}

\subsection{Sincerity}

Sincerity is shown when personnel are able to give advice or suggest the best product or services suit the needs of the custo mers. This action will lead customers to build their trust in the organisation's ability in handling their problems or needs. In a collectivist society with high power distance and high uncertainty avoidance, dimensions such as sincerity are extremely important (Raajpoot, 2004). Asians reluctance to take higher risks in making decisions could slow down the service consumption process in such societies (Lee, Garbarino, \& Lerman, 2007). Hence, the service consumption risk in Asian societies can be minimised through sincerity during service provision. This is where the front-line staff is suggested to earn a reputation of providing proactive, well-mannered, and customised advice to the customers (Raajpoot, 2004). A recent study by Kashif et al. (2016) found sincerity as one of the dimensions that highly contributes to customer satisfaction. This leads the study to hypothesise:

\section{H4. Favourable customer perceptions of sincerity positively influence customer satisfaction towards Islamic banks.}

\subsection{Personalisation}

Personalisation refers to customisation and individualised attention, and to some extents, it is addressed in the empathy dimension of SERVQUAL (Rajpoot, 2004). According to Rajpoot (2004), personalisation is included due to the fact that Asians scored higher on power distance which translates as the customers' desire for individual identity despite being parts of a group (Winsted, 1997). Even though Asian is known as a collectivist people, one's need to be recognised or individually treated is still important as each individual is still open to maintaining the status quo, hence, public recognition of one's social status is very important in societies with high power distance (Hofstede, 1980). Accordingly, personalisation refers to the importance of service providers to focus on individual needs and to customise the service. Offering highly customised solutions to customers have been found to help marketers in attracting more customers (Imrie, 2013). Kashif et al. (2016) also showed that personalisation is an important dimension that influences customer satisfaction. Therefore, it is hypothesised that:

$H_{5 .}$ Favourable customer perceptions of personalisation positively influence customer satisfaction towards Islamic banks.

\subsection{Formality}

Karami, Malek, and Dubinsky (2016) proposed that formality denotes how customers evaluate service company employees' aptitude to uphold their social distance by demonstrating decorous behaviour, acknowledging families and showing total courtesy to customers. In other words, formality refers to the act of aligning with customs or etiquette. It could be said that the formality of an organisation is being evaluated through the maintenance of their social distance with the customers. This relates to the acknowledgement of social status in high context cultures. Accordingly, people living in high-contact cultures like to stay close to each other and value the relationship within their social hierarchy (Hofstede, 200I). In this regard, people prefer to stay formal during service encounters and like to see formal attire by the staff in a service setting (Witkowski \& Wolfinbarger, 200I). In order to serve this cultural character, employees are suggested to be formal, pay full attention and do not use improper language during service encounters (Kashif et al., 2015). Also, employees also should follow the formal dress code, exhibit w orkrelated etiquettes, and maintain formal attire (Witkowski \& Wolfinbarger, 200I). Raajpoot (2004) revealed that formality is one of the top three important dimensions contributing to customer satisfaction. Hence, this study hypothesised:

$H_{6}$. Favourable customer perceptions of formality positively influence customer satisfaction towards Islamic banks. 


\subsection{Compliance}

In addition to the six dimensions of PAKSERV, this study proposed the inclusion of compliance as one of the important service quality measurement. Compliance, as defined by Othman and Owen (200I), refers to the ability to adhere to Islamic Law and operate under the principles of Islamic banking and economy. Past literature shows that compliance is significant in measuring the Islamic bank's service quality and it is in line with cross-cultural and religious differences between two key customer segments, Muslims and non-Muslims (Amin \& Isa, 2008). It is imperative to add this dimension into the PAKSERV model as in Malaysia, 40 per cent of Muslims were motivated to use product and service of Islamic banks due to the compliance factor (Haron, Ahmad, \& Planisek, 1994). Therefore, it is hypothesised that:

$H$. Favourable customer perceptions of compliance positively influence customer satisfaction towards Islamic banks.

\subsection{Customer Satisfaction and Loyalty}

The feeling of satisfaction is obtained by customers' when their expectations are successfully met by the service provider (Kashif et al., 2015). Customer satisfaction determines the likelihood of repurchase intentions which would create loyalty (Iacobucci, Grayson, \& Ostrom, 1994). The lifetime loyalty of a customer towards the service organisations depends heavily on their satisfaction with the offer (Ndubisi, 2007). The core advantage of satisfied customers is that they spread positive word-ofmouth to their friends and other members of the reference group (Gerrard \& Cunningham, 200I). In this regard, past studies demonstrated that loyalty is driven by customers' satisfaction (Ladhari et al., 20I I). On the other hand, Kashif et al. (20I5) also found that there is a great relationship between customer satisfaction and loyalty. Considering the results of past research, gaining a high level of customer satisfaction is important for a company's achievement as a satisfied customer will return and retain. Thus, keeping this in mind, the following hypothesis is formulated:

$H_{8 .}$ Customer satisfaction positively influences loyalty to Islamic banks.

\section{Methodology \\ 3.I Measurement}

The study adapted scales from previous literature: 34 items for service quality dimensions (Othman \& Owen, 200I; Raajpoot, 2004), items for satisfaction (Amin \& Isa, 2008) and six items for loyalty (Kashif et al., 20I6). A six-point Likert-type scale (Strongly disagree I - Strongly agree 7) was used in this study as it could provide higher reliability than the five-point Likert's scale (Chomeya, 2010).

\subsection{Sample}

A non-probability sampling technique was used in this study as the list of Islamic banking customers in Malaysia is inaccessible due to legal and privacy issue (Osman, 20II). The target respondents were adult consumers (above I8 years old) who live and/or work within the Klang Valley areas and have interactions with any Islamic bank within six months. The survey was personally administered where the respondent was first asked on his/her willingness to participate in the study. Once the agreement is received from the respondent, the general purpose of the survey was explained, and the questionnaire was given to them right away. A total of 400 questionnaires were distributed, but only 374 questionnaires were returned, and 363 questionnaires were valid to be further analysed, representing a response rate of 90.75 per cent.

The sample consisted of 37.2 per cent males and 62.8 per cent females. Majority of the respondents are Malay Muslims which accounted for 80.2 per cent of the respondents while the other 19.8 per cent consists of Chinese, Indian and others. The major age group is between 26 to 35 years old (3I.9 per cent) followed by 18 to 25 years old ( 24.8 per cent) and 36 to 45 years old (22.6 per cent). Most of the respondents are married (53.4 per cent), hold a Bachelor's degree (47.I per cent), and work in the public sector (38.8 per cent). The highest income group is between RM 2,00I to RM 4,000 (29.8 per cent) followed by less than RM2,000 (2I.2 per cent) and RM4,00I to RM6,000 (I9.3 per cent).

In term of banking experience, almost two-thirds of the respondents have accounts with both Islamic bank and conventional bank (70.2 per cent). Majority of the respondents have used Islamic banking services for more than ten years (30 per cent). Saving account is the main product used (90.9 per cent) while for financing, the highest used is for vehicle financing (22.3 per cent). The main reason respondents used Islamic banking is because of religious factor (60.6 per cent), followed by a low financing rate (II.8\%) and friend or family recommendation (I I.6\%). 


\section{Findings}

The data was analysed using PLS-SEM. The analysis consists of a two-step approach. It primarily comprises of a comprehensive valuation of the measurement model at the item level, followed by evaluation of the higher-order level and analysis of the posited structural relationships. The process involves separate assessments which are known as measurement models and the structural model (Hair, Hult, Ringle, \& Sarstedt, 20I4).

\section{I Measurement Model Results}

The purpose of the measurement model is to assess the internal consistency reliability, convergent validity and discriminant validity of the study constructs. Table I show that the values of Cronbach's alpha and composite reliability (CR) all exceed the recommended threshold value of 0.7. This shows that all the constructs have a high level of internal consistency reliability (Hair, Black, Babin, \& Anderson, 2010). The constructs' convergent validity is also established as the AVE values are all above the required minimum level of 0.50 (Hair et al., 2010).

Table I. Reliability and Convergent Validity

\begin{tabular}{|c|c|c|c|c|c|}
\hline Construct & Item & Loadings & Alpha & $\mathrm{CR}$ & AVE \\
\hline \multirow[t]{4}{*}{ Reliability } & ReaI & 0.853 & 0.865 & 0.908 & 0.712 \\
\hline & Rea2 & 0.896 & & & \\
\hline & Rea3 & 0.813 & & & \\
\hline & Rea4 & $0.8 \mathrm{II}$ & & & \\
\hline \multirow[t]{5}{*}{ Tangibility } & TanI & 0.838 & $0.89 \mathrm{I}$ & 0.920 & 0.697 \\
\hline & $\operatorname{Tan} 2$ & 0.870 & & & \\
\hline & Tan3 & 0.794 & & & \\
\hline & Tan4 & 0.818 & & & \\
\hline & Tan5 & $0.85 \mathrm{I}$ & & & \\
\hline \multirow[t]{4}{*}{ Assurance } & AnsI & 0.845 & 0.856 & 0.902 & 0.697 \\
\hline & Ans2 & 0.858 & & & \\
\hline & Ans3 & 0.820 & & & \\
\hline & Ans4 & 0.815 & & & \\
\hline \multirow[t]{4}{*}{ Sincerity } & $\operatorname{Sin} I$ & $0.9 \mathrm{I} 4$ & $0.9 \mathrm{I} 4$ & 0.940 & 0.796 \\
\hline & $\operatorname{Sin} 2$ & 0.886 & & & \\
\hline & $\operatorname{Sin} 3$ & 0.908 & & & \\
\hline & $\operatorname{Sin} 4$ & 0.859 & & & \\
\hline \multirow[t]{4}{*}{ Formality } & ForI & 0.803 & 0.837 & 0.891 & 0.672 \\
\hline & For2 & 0.872 & & & \\
\hline & For3 & 0.879 & & & \\
\hline & For4 & 0.716 & & & \\
\hline \multirow[t]{4}{*}{ Personalization } & PerI & 0.760 & $0.88 \mathrm{I}$ & 0.918 & 0.738 \\
\hline & Per2 & 0.884 & & & \\
\hline & Per3 & 0.903 & & & \\
\hline & Per4 & 0.882 & & & \\
\hline \multirow[t]{9}{*}{ Compliance } & ComI & 0.794 & 0.933 & 0.944 & 0.653 \\
\hline & Com2 & $0.75 \mathrm{I}$ & & & \\
\hline & Com3 & 0.788 & & & \\
\hline & Com 4 & 0.772 & & & \\
\hline & Com5 & 0.823 & & & \\
\hline & Com6 & 0.856 & & & \\
\hline & Com7 & 0.830 & & & \\
\hline & Com8 & 0.807 & & & \\
\hline & Com9 & 0.847 & & & \\
\hline \multirow[t]{3}{*}{ Satisfaction } & Cus I & 0.918 & 0.937 & 0.955 & $0.84 \mathrm{I}$ \\
\hline & Cus2 & 0.918 & & & \\
\hline & Cus3 & 0.904 & & & \\
\hline
\end{tabular}




\begin{tabular}{llllll}
\hline & Cus4 & 0.928 & & & \\
\hline Loyalty & LoyI & 0.871 & 0.945 & 0.955 & \\
Loy2 & 0.897 & & \\
Loy3 & 0.880 & & \\
Loy4 & 0.894 & & \\
Loy5 & 0.887 & & \\
Loy6 & 0.875 & & \\
\hline
\end{tabular}

Table 2 shows the results of the Fornell-Larcker criterion assessment with the square root of the reflective constructs' AVE on the diagonal and the correlations between the constructs in the lower left triangle. Overall, the square roots of the reflective constructs AVE are higher than the correlations of these constructs with other latent variables in the path model. Consequently, the discriminant validity is established as the indicator's loadings on all constructs are higher than their crossloadings with other constructs.

Table 2. Discriminant Validity (Fornell-Larcker Criterion)

\begin{tabular}{|c|c|c|c|c|c|c|c|c|c|}
\hline & (I) & (2) & (3) & (4) & (5) & (6) & (7) & (8) & (9) \\
\hline$\overline{\text { Reliability (I) }}$ & 0.844 & & & & & & & & \\
\hline Tangibility (2) & 0.656 & 0.835 & & & & & & & \\
\hline Assurance (3) & $0.67 \mathrm{I}$ & $0.73 \mathrm{I}$ & 0.835 & & & & & & \\
\hline Sincerity (4) & 0.673 & 0.688 & $0.72 \mathrm{I}$ & 0.892 & & & & & \\
\hline Personalization (5) & 0.600 & 0.615 & $0.63 \mathrm{I}$ & 0.761 & 0.859 & & & & \\
\hline Formality (6) & 0.608 & 0.596 & $0.7 \mathrm{I5}$ & 0.666 & 0.624 & 0.820 & & & \\
\hline Compliance (7) & 0.608 & 0.596 & $0.58 \mathrm{I}$ & 0.666 & 0.624 & 0.594 & 0.808 & & \\
\hline Satisfaction (8) & 0.646 & 0.648 & 0.636 & 0.753 & 0.709 & 0.701 & 0.701 & 0.917 & \\
\hline Loyalty (9) & 0.601 & 0.635 & 0.609 & 0.692 & 0.652 & 0.644 & 0.699 & 0.806 & 0.884 \\
\hline
\end{tabular}

Note: diagonal represents the square root of the $A V E$, and the off-diagonal represent the correlations

\subsection{Structural Model Results}

The structural or inner model concerns the relationship between constructs or latent variable as hypothesised in the research model (Hair et al., 20I4). For this, bootstrapping $(n=363$, sample $=5000)$ was applied. Table 3 describes the summarised results of the proposed structural model with regards to the path coefficients standard error and t-statistics. The results show that five dimensions have a significant influence on customer satisfaction towards Malaysian Islamic banks. Compliance, the additional dimension, demonstrates the largest path coefficient $(\beta=0.2568)$, followed by sincerity $(\beta=0.2330)$, personalisation ( $\beta=0.1654)$, formality $(\beta=0.1245)$ and reliability $(\beta=0.1122)$. The two insignificant dimensions are assurance and tangibility. The findings also show that satisfaction has a significant influence on loyalty $(\beta=0.806 \mathrm{I})$. On the other hand, the $\mathrm{R}^{2}$ values for customer satisfaction and loyalty were 0.6797 and 0.649 indicating that satisfaction can explain $64.9 \%$ of the variance in loyalty while service quality explained $67.97 \%$ of the variance in satisfaction.

Table 3. Hypotheses Testing Results

\begin{tabular}{lcccc}
\hline \multicolumn{1}{c}{ Hypothesis } & Path Coeff. & T Stats & P Values & Decision \\
\hline HI: Reliability $\rightarrow$ Satisfaction & 0.1 I2 & 2.I2I & 0.034 & Supported \\
\hline H2: Tangibility $\rightarrow$ Satisfaction & 0.085 & I.I I5 & 0.265 n.s & Not supported \\
\hline H3: Assurance $\rightarrow$ Satisfaction & -0.012 & 0.185 & 0.853 n.s & Not supported \\
\hline H4: Sincerity $\rightarrow$ Satisfaction & 0.233 & 3.314 & $0.00 I^{\text {Sups }}$ & Suported \\
\hline
\end{tabular}




\begin{tabular}{|c|c|c|c|c|}
\hline H5: Personalization $\rightarrow$ Satisfaction & 0.165 & 2.912 & $0.004^{-1}$ & Supported \\
\hline H6: Formality $\rightarrow$ Satisfaction & 0.125 & $2.06 \mathrm{I}$ & 0.039 & Supported \\
\hline H7: Compliance $\rightarrow$ Satisfaction & 0.257 & 3.602 & $0.003^{x}$ & Supported \\
\hline H8: Satisfaction $\rightarrow$ Loyalty & 0.806 & $25.3 \mathrm{I}$ & $0.000^{2}$ & Supported \\
\hline
\end{tabular}

Note: ${ }^{2} p<0.01$, $p<0.05$, n.s not significant

\section{Discussions}

Maintaining a high-quality performance is vital, especially in the context of a service organisation where quality could determine its success and survival (Parasuraman et al., 1985). In order to deepen understanding, various studies and arguments have been discussed in the most suitable tools to measure service quality. However, the available instruments have been criticised as most of it are developed in Western countries which has a different culture than the Asian nations (Amin \& Isa, 2008; Cui, Lewis, \& Park, 2003; Kashif et al., 2016; Prakash \& Mohanty, 2013; Strandberg, Wahlberg, \& Ohman, 2012). Following these arguments, this study incorporates a PAKSERV scale developed according to the Asian culture and another dimension adapted from the CARTER scale, which is 'compliance' to suit the Islamic banking context. Eight hypotheses were proposed, but only six hypotheses are supported. Two hypotheses that are not supported are tangibility and assurance.

Findings of this study provide evidence that the service quality dimensions that influence satisfaction towards Islamic banks in Malaysia are elements that are tied to culture. The factor that influences satisfaction the most is the additional dimension, "compliance". This is due to the fact that the majority of respondents are Malay Muslims, and the main factor they choose Islamic banking is because it is halal (permissible by the Islamic laws). "Compliance" is the attribute that distinguishes Islamic banks from conventional banks. Thus this dimension indicates religious belief, a critical cultural element in consumer decision making (Souiden \& Rani, 2015). This finding also supported past research that "compliance" is an important dimension of service quality for Islamic banks (Othman \& Owen, 200I). Indirectly, this finding suggested that regardless of whether customers understand or not how the system works, they need to deal with a bank that offers Islamic banking system due to religious obligation. As such, it is important for Islamic banking staff to portray a sincere and trustable image that would decrease customer's uncertainty thoughts. By doing so, customers perceive that they have made the right decisions by interacting or following the employee's sincere advice which makes them satisfied with the service.

The next significant factors are "sincerity", followed by "personalisation", "formality" and "reliability". These findings are similar to Kashif et al. (2015) and Kashif et al. (2016), where they found these four dimensions have a significant influence on satisfaction. Sincerity refers to consumer's evaluation of the genuineness of service personnel which reflects the authenticity and originality of the personnel attitude while providing the service (Raajpoot, 2004). With regards to culture, Malaysia as a collectivist society is associated with uncertainty avoidance which causes a dimension such as sincerity to be extremely important (Raajpoot, 2004). A high score on the community's uncertainty avoidance shows the importance of sincere advice which customers expect as part of a service quality delivery. In this light, Asians are not ready to take higher risks in many decisions which could slow down the service process in such societies and appreciate even small gesture of sincerity been projected by others (Lee et al., 2007). Meanwhile, the significant relationships between "personalisation" and "formality" dimensions and satisfaction substantiated that Malaysia is high in power distance. Even though known as collectivist people, a high score on power distance reveals the customers' desire for individual identity despite being part of a group (Winsted, 1997) and public recognition of one's social status is very important (Hofstede, 1980). Therefore, while "personalisation" is an important element, the significance of "formality" dimension indicates that customers expect employees to perform the services in alignment with customs or etiquette. As "formality" is evaluated through the maintenance of social distance with the customers, banks' employees must deliver the services following formal procedures.

In contrary, "tangibility" and "assurance" dimensions, however, were found to be insignificant in this study which is in line with few past literatures in Islamic banking (Badara, Mat, Mujtaba, Al-Refai, Badara \& Abubakar, 20I3; Rehman, 20I2; Shariff, 2013). Besides, the study also reinforces the importance of satisfaction towards loyalty as established in past literature. Thus, to retain the customers, Islamic banks managers must ensure that customers are highly satisfied. This study provides evidence that in a collectivist society like Malaysia, satisfaction can be enhanced by emphasising on the elements of halal and delivering services that are sincere; personalise, yet formal and reliable. 


\section{Conclusions}

Despite numerous researches on Islamic bank's service quality, the ones that investigate cultural elements are still lacking. This study enriches the literatures on Islamic banks as it incorporates the "compliance" dimension into a cultural-based service quality scale, PARKSERV. 'Compliance" denotes an important religious and cultural component for Islamic banks and it is first introduced in CARTER model. Both PARKSERV and CARTER are developed from the well-established SERVQUAL instrument. Therefore, integrating the religious dimension, "compliance" into a cultural based scale contributes to a more comprehensive knowledge on service quality. The findings support that this additional dimension named "compliance" has a significant influence on customers' satisfaction towards Malaysian Islamic banks together with "sincerity", "personalisation", "formality" and "reliability" dimensions of service quality. This is particularly useful as Islamic banks are generally opera ting in non-Western countries in which the environment are culturally dissimilar. Thus this empirical evidence provides insights for Islamic banks' managers in countries like Malaysia on how to further enhance the quality of their service deliveries.

Nevertheless as this research is only focusing on Malaysia, it would be interesting if this study can be replicated in other countries with similar and/or different cultural background to further understand these cultural dimensions of service quality. The study also offers the potential to be replicated in other halal service industries such as Takaful, tourism, restaurant and so on. Comparing the results with other countries and/or industries is expected to provide fresh insights for marketers, particularly to those having business in different regions.

\section{References}

Al-Dimasqi, A. M. (2006). Mawi'zatalMukminin Min IhyaUlum al-Din Li Imam Ghazali. (TransI). Kuala Lumpur: DarulFajr. Al-Zaabi, O. S. H. A. (2006). Quality service in the UAE. (Doctoral thesis, Durham University, Durham, UK).

Amin, M., \& Isa, Z. (2008). An examination of the relationship between service quality perception and customer satisfaction: A SEM approach towards Malaysian Islamic banking. International Journal of Islamic and Middle Eastern Finance and Management, I(3), I9I-209.

Amine, A. (1998). Consumers' true brand loyalty: The central role of commitment. Journal of Strategic Marketing, 6, 305319.

Badara, M. S., Mat, N. K. M., Mujtaba, A. M., Al-Refai, A. N., Badara, A. M., \& Abubakar, F. M. (2013). The direct effect of service quality dimensions on customer satisfaction and customer loyalty in Nigerian Islamic bank. Scientific \& Academic Publishing Management, 3(I), 6-I I.

Berry, L. L., Lepkowith, E. K., \& Clark, T. (I988). In services, what's in a name? Harvard Business Review, 66, 28-30.

Camarero, C. (2007). Relationship orientation or service quality? What is the trigger of performance in financial and insurance services? International Journal of Bank Marketing, 25(6), 406-426.

Chomeya, R. (2010). Quality of psychology test between Likert scale 5 and 6 points. Journal of Social Sciences, 6(3), 399403.

Choudhury, K. (2013). Service quality and customers' purchase intentions: An empirical study of the Indian banking sector. International Journal of Bank Marketing, 3I(7), 529-543.

Cui, C. C., Lewis, B. R., \& Park, W. (2003). Service quality measurement in the banking sector in Korea. International Journal of Bank Marketing, 21, I9I-20I.

Fisk, R. P., \& Grove, S. J. (1995). Service performance as drama: Quality implications and measurement. In P. Kunst \& J. Lemmink (Eds.), Managing Service Quality (pp. I07-I19).

Gerrard, P., \& Cunningham, B. (200I). Singapore's undergraduates: How they choose which bank to patronise. International Journal of Bank Marketing, I9(3), I04-I I4.

Hair, J. F., Black, W. C., Babin, B. J., \& Anderson, R. E. (2010). Multivariate data analysis, 7. Upper Saddle River, New Jersey: Pearson Prentice Hall.

Hair, J. F., Hult, G. T. M., Ringle, C. M., \& Sarstedt, M. (20I4). A primer on partial least squares structural equation modelling (PLS-SEM). Thousand Oaks: Sage.

Haron, S., Ahmad, N., \& Planisek, S. L. (I994). Bank patronage factors of Muslim and Non-Muslim customers. International Journal of Bank Marketing, I2(I), 32-40. https://doi.org/I0.I I08/02652329410049599

Hawke, A., \& Heffernan, T. W. (2006). Interpersonal liking in lender-customer relationships in the Australian banking sector. International Journal of Bank Marketing, 24(3), I40-I57.

Hofstede, G. (1980). Culture's consequences: International differences in work-related values. Beverly Hills: Sage.

Hofstede, G. (200I). Culture's consequences: Comparing values, behaviours, institutions, and organisations across nations. Thousand Oaks, CA: Sage.

Iacobucci, D., Grayson, K., \& Ostrom, A. (1994). Customer satisfaction fables. Sloan Management Review, 35(4), 93-96.

Imrie, B. C. (2013). The influence of social capital on service quality evaluation. Management Decision, 5I(4), 87I-889. 
Jain, S., \& Jain, S. K. (2015). Does the outcome quality matter? An investigation in the context of banking services in an emerging market. Journal of Consumer Marketing, 32(5), 34I-355.

Jay, K., Zhang, T., \& Bilgihan, A. (2015). Customer loyalty: A review and future directions with a special focus on the hospitality industry. International Journal of Contemporary Hospitality Management, 27(3), $379-414$. https://doi.org/http://dx.doi.org/I0.I I08/MRR-09-2015-02I6

Karami, M., Malek, M. M., \& Dubinsky, A. J. (2016). Cultural values and consumers' expectations and perceptions of service encounter quality. International Journal of Pharmaceutical and Healthcare Marketing, IO(I), 2-26.

Kashif, M., Shukran, S. W. S., Rehman, M. A., \& Sarifuddin, S. (2015). Customer satisfaction and loyalty in Malaysian Islamic banks: A PAKSERV investigation. International Joumal of Bank Marketing, 33(I), 23-40.

Kashif, Muhammad, Rehman, M. A., \& Pilelienè, L. (2016). Customer perceived service quality and loyalty in Islamic banks. The TQM Joumal, 28(I), 62-78. https://doi.org/I0.II08/TQM-0I-20I4-0006

Kim, C. S., \& Aggarwal, P. (2016). The customer is king: Culture-based unintended consequences of modern marketing. Journal of Consumer Marketing, 33(3), 193-201.

Kueh, K., \& Voon, B. H. (2007). Culture and service quality expectations: evidence from generation Y consumers in Malaysia. Managing Service Quality, I7(6), 656-680.

Ladhari, R. (2008). Alternative measures of service quality: A review. Managing Service Quality, I8(I), 65-86.

Ladhari, R., Souiden, N., \& Ladhari, I. (20II). Determinants of loyalty and recommendation: The role of perceived service quality, emotional satisfaction and image. Journal of Financial Services Marketing, I6(2), I I I-I24.

Laroche, M., Uelschy, L. C., Abe, S., \& Cleveland, M. Yannopoulos, P. P. (2004). Service quality perceptions and customer satisfaction: Evaluating the role of culture. Journal of International Marketing, I2(3), 58-85.

Lee, J. A., Garbarino, E., \& Lerman, D. (2007). How cultural differences in uncertainty avoidance affect product perceptions. International Marketing Review, 24(3), 330-349.

Malhotra, N. K., Ulgado, F. M., Agarwal, J., Shainesh, G., \& Wu, L. (2005). Dimensions of service quality in developed and developing economies: Multi-country cross-cultural comparisons. International Marketing Review, 22(3), $256-278$.

Martinez, J. A., \& Martinez, L. C. (20I0). Rethinking perceived service quality: An alternative to hierarchical and multidimensional models. Total Quality Management and Business Excellence, 2I(I), 93-I I8.

Ndubisi, N. O. (2007). Relationship marketing and customer loyalty. Marketing Intelligence \& Planning, 25(I), $98-106$.

Osman, 'I. (20I I). The impact of corporate image on customer loyalty of Islamic Banks in Malaysia: Integrating resource-based and institutional theory (Unpublished doctoral dissertation). International Islamic University Malaysia, Malaysia.

Othman, A., \& Owen, L. (200I). Adopting and measuring customer service quality (SQ) in Islamic Banks: A case study in Kuwait Finance House. International Joumal of Islamic Financial Services, 3(I), I-26.

Parasuraman, A., Zeithaml, V. A., \& Berry, L. L. (I985). A conceptual model of service quality and its implication for future research ( SERVQUAL ). Journal of Marketing, 49, 4I-50.

Parasuraman, A., Zeithaml, V. A., \& Berry, L. L. (I988). SERVQUAL: A multiple-item scale for measuring customer perceptions of service quality. Journal of Retail, 64(I), I4-40.

Prakash, A., \& Mohanty, R. P. (2013). Understanding service quality. Production Planning and Control, $24(12)$, I050-I065.

Raajpoot, N. (2004). Reconceptualising service encounter quality in non-western context. Journal of Service Research, $7(2)$, I8I-20I.

Reeves, C. A., \& Bednar, D. A. (1994). Defining quality: Alternatives and implications. Academy of Management Review, I9(3), 4I9-445.

Rehman, A. A. (2012). Customer satisfaction and service quality in Islamic banking. Qualitative Research in Financial Markets, $4(2 / 3), 165-175$.

Saunders, S. G. (2008). Measuring and applying the PAKSERV service quality construct: Evidence from a South African cultural context. Managing Service Quality, I8(5), 442-456.

Shafie, S., Azmi, W. N. W., \& Haron, S. (2004). Adopting and measuring customer service quality in Islamic banks: A case study of Bank Islam Malaysia Berhad. Journal of Muamalat and Islamic Finance Research, I(I), 2-I9.

Shariff, R. A. B. M. (2013). Service quality in Islamic and conventional banks in Malaysia: An explorative and comparative analysis (Unpublished doctoral dissertation). Durham University, UK.

Souiden, N., \& Rani, M. (2015). Consumer attitudes and purchase intentions toward Islamic banks: The influence of religiosity. International Journal of Bank Marketing, 33(2), I43-I6I.

Strandberg, C., Wahlberg, O., \& Ohman, P. (2012). Challenges in serving the mass affluent segment: Bank customer perceptions of service quality. Managing Service Quality, 22(4), 359-385.

Tahir, M. T., \& Bakar, N. M. A. (2007). Service quality gap and customers' satisfaction of commercial banks in Malaysia. International Review of Business Research Papers, 3(4), 327-336.

Tsoukatos, E., \& Rand, G. K. (2007). Cultural influences on service quality and customer satisfaction: Evidence from Greek 
insurance. Managing Service Quality, I7(4), 467-485.

Veloutsou, C., Daskou, S., \& Daskou, A. (2004). Are the determinants of bank loyalty brand specific? Journal of Financial Services Marketing, $9(2), \mathrm{I} 13-125$.

Winsted, F. K. (1997). The service experience in two cultures: A behavioural perspective. Journal of Retailing, 73(3), 337360.

Witkowski, T. H., \& Wolfinbarger, M. F. (200I). The formality dimension of service quality in Thailand and Japan. Advances in Consumer Research, 28, I53-I60.

Zeithaml, V. A., Berry, L. L., \& Parasuraman, A. (1996). The behavioral consequences of service quality. Journal of Marketing, $60(2), 3 I-46$.

\section{Copyrights}

Copyright for this article is retained by the author(s), with first publication rights granted to the journal. This is an open-access article distributed under the terms and conditions of the Creative Commons Attribution license (http://creativecommons.org/licenses/by/4.0/). 